\title{
Removal of Heavy Metal Ions from Water and Wastewaters by Sulfur-Containing Precipitation Agents
}

\author{
Alina Pohl iD \\ Received: 6 March 2020 / Accepted: 14 September 2020 /Published online: 28 September 2020 \\ (C) The Author(s) 2020
}

\begin{abstract}
Restrictive requirements for maximum concentrations of metals introduced into the environment lead to search for effective methods of their removal. Chemical precipitation using hydroxides or sulfides is one of the most commonly used methods for removing metals from water and wastewater. The process is simple and inexpensive. However, during metal hydroxide precipitation, large amounts of solids are formed. As a result, metal hydroxide is getting amphoteric and it can go back into the solution. On the other hand, use of sulfides is characterized by lower solubility compared with that of metal hydroxides, so a higher degree of metal reduction can be achieved in a shorter time. Disadvantages of that process are very low solubility of metal sulfides, highly sensitive process to the dosing of the precipitation agent, and the risks of emission of toxic hydrogen sulfide. All these restrictions forced to search for new and effective precipitants. Potassium/sodium thiocarbonate (STC) and 2,4,6-trimercaptotiazine (TMT) are widely used. Dithiocarbamate (DTC) compounds are also used, e.g., sodium dimethyldithiocarbamate (SDTC), and ligands for permanent metal binding, e.g., 1,3-benzenediamidoethanethiol $\left(\mathrm{BDETH}_{2}\right)$, 2,6-pyridinediamidoethanethiol (PyDET), a pyridine-based thiol ligand (DTPY) or ligands with open chains containing many sulfur atoms, using of a tetrahedral bonding arrangement around a central metal atom. The possibility of improving the efficiency of metal
\end{abstract}

A. Pohl $(\bowtie)$

Institute of Environmental Engineering, Polish Academy of

Sciences in Zabrze, M. Skłodowskiej-Curie 34 Street,

41-819 Zabrze, Poland

e-mail: alina.poh1@ipis.zabrze.pl precipitation is obtained by using a higher dose of precipitating agent. However, toxic byproducts are often produced. It is required that the precipitation agents not only effectively remove metal ions from the solution but also effectively bind with dyes or metal complexes.

Keywords Metal sulfide precipitation · Chelating agents · Dithiocarbamate compounds · A synthetic chelating ligand

\section{Introduction}

As civilization develops, the level of environmental pollution with heavy metals intensifies. This pollution has an influence on air, water, and soil contamination by dust, industrial gases, sewage, waste, and coal combustion products containing heavy metals (Nocoń et al. 2006; Barbusiński and Nocoń 2011). The persistent nature of these non-biodegradable pollutants is very dangerous. They tend to accumulate in living organisms. After entering the food chain, they undergo biomagnification processes and finally accumulate in the human body. Heavy metals are classified as substances that pose a particular threat to human health due to their possible toxic or carcinogenic effects (Barakat 2011; Fu and Wang 2011).

As a result of many industrial processes, sewage is generated, and it contains a number of heavy metals, such as zinc, copper, nickel, mercury, cadmium, lead, or chromium (Fu and Wang 2011). 
Metals in wastewater can come from fertilizers or pesticides as well as from the plating, tanning, dyeing, textile, or electrochemical industries (Koc-Jurczyk 2013). The most commonly used methods of metal removal from wastewater include methods based on the precipitation of metal hydroxides or sulfides, ion exchange on chelating ion exchangers, evaporation in vacuum evaporators, reverse osmosis process, membrane filtration, electrochemical processing technologies, adsorption on various materials, co-precipitation with ferrite, or the use of starch or borohydride xanthates to reduce metal ions to metallic form (Fu et al. 2006a; Barakat 2011; Thomas et al. 2014).

The scope of this work is to set the methods for removing metals from water and wastewater, comparing their effectiveness with particular emphasis on methods based on sulfidation.

\section{Methods for Removing Metals from Wastewater and Water-Chemical Precipitation}

Precipitation is a method in which contaminants (in dissolved or suspended form) are separated from the solution as a sediment, which can then be filtered, centrifuged, or otherwise separated from the liquid part (US Environmental Protection Agency (US EPA) 2000, Fu and Wang 2011). The precipitate forms as a result of the formation of a complex between the precipitation agent and heavy metal ions, which reduces the bioavailability of metals (Sheoran and Sheoran 2006).

Chemical precipitation is an effective and widely used process in the industry. It is characterized by simplicity and it is inexpensive to operate. It can be used to remove pollutants from municipal and industrial wastewater. It can also be used for water softening, heavy metal removal from metal plating wastes, oil and grease removal from emulsified solutions, and phosphate removal from wash-waters and other wastewater (US Environmental Protection Agency (US EPA) 2000, Fu and Wang 2011). In the technological system, the obtained precipitate is separated from the solution by sedimentation or filtration, and the treated water is then decanted and respectively discharged or re-used (Fig. 1) (Fu and Wang 2011).

One of the most important parameters regulating chemical precipitation is $\mathrm{pH}$. For the coagulation process, $\mathrm{pH}$ is a critical parameter. Generation of polymeric coagulant forms with a highly positive charge, considered the most effective, occurs at a $\mathrm{pH}$ value of $<6.5$, which in practice means the acidification of the medium to be purified before the coagulation stage (Mroczko and Zimoch 2018).

Effectiveness of the chemical precipitation is also affected by the type and concentration of metal ions present in the solution, precipitation reagent used, reaction conditions, and presence of other compounds that can inhibit the reaction. The quantities of necessary chemicals used in the process are difficult to calculate. It depends on the $\mathrm{pH}$ and alkalinity of the wastewater, phosphate level, point of injection and mixing modes, among other factors (Barakat 2011, US Environmental Protection Agency (US EPA) 2000). In practice, the metal precipitation does not coincide with the theoretical characteristics of their solubility and $\mathrm{pH}$ range specified for solutions containing single metal cations (Grabas 2009). Accurate doses should be determined by jar tests and confirmed by field evaluations. In wastewater treatment, the most commonly used are:

- $\quad$ Lime - calcium oxide, $\mathrm{CaO}$;

- Ferrous sulfate, $\mathrm{Fe}\left(\mathrm{SO}_{4}\right)_{3}$;

- Alum or filter alum, $\mathrm{Al}_{2}\left(\mathrm{SO}_{4}\right)_{3} \cdot 14 \mathrm{H}_{2} \mathrm{O}$;

- Ferric chloride, $\mathrm{FeCl}_{3}$;

- Polymer (US Environmental Protection Agency (US EPA) 2000).

In the coagulation process, traditional hydrolyzing aluminum salts such as aluminum sulfate or aluminum chloride are often used. Replacing them with new coagulant generation, represented by pre-hydrolyzed aluminum salts with a high degree of polymerization with the general formula $\mathrm{Al}_{\mathrm{n}}(\mathrm{OH})_{\mathrm{m}} \mathrm{Cl}_{3 \mathrm{n}-\mathrm{m}}$, allows not only for more efficient treatment but also to minimize the undesirable effects of chemical dosing and higher efficiency over a wide range of $\mathrm{pH}$ and temperature (Mroczko and Zimoch 2018). As pre-hydrolyzed coagulants, polyaluminium chloride, sulfate (VI) polyaluminium, and poly iron (III) may be mentioned (Nawrocki and Biłozor 2010; Krupińska 2011).

Conventional chemical precipitation methods include hydroxide precipitation and sulfide precipitation.

\section{Metal Hydroxide Precipitation}

In a process of metal precipitation as hydroxides, an alkaline agent is used, which raises the $\mathrm{pH}$ of the 
Fig. 1 Processes of a conventional metals precipitation treatment plant (Wang et al. 2004)

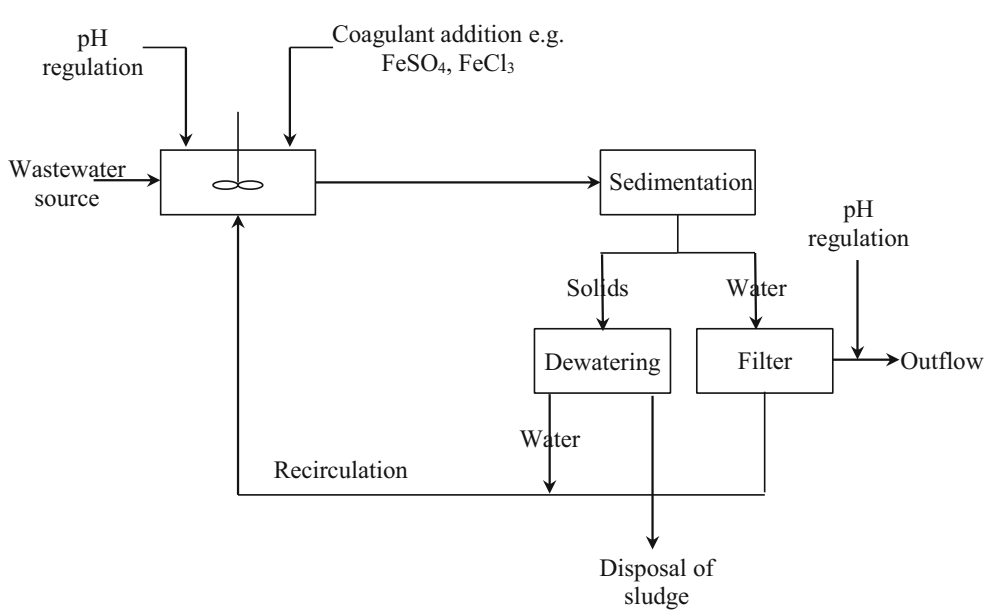

solution, resulting in a decrease of the metal ion solubility, and thus their precipitation from the solvent. For this purpose, lime or sodium hydroxide is most often used. The mechanism of heavy metal removal by precipitation of metal hydroxides is shown in Eq. 1:

$\mathrm{M}^{2+}+2(\mathrm{OH})^{-} \leftrightarrow \mathrm{M}(\mathrm{OH})_{2}$

where $\mathrm{M}^{2+}$ and $\mathrm{OH}^{-}$represent the dissolved metal ions and the precipitant, respectively, while $\mathrm{M}(\mathrm{OH})_{2}$ is the insoluble metal hydroxide (Wang et al. 2004).

For the precipitation of heavy metals from the solution, calcium carbonate, calcium hydroxide (slaked lime), calcium oxide (quicklime), sodium carbonate (soda ash), sodium hydroxide, and ammonium hydroxide can be used (Skousen et al. 2000; Egiebor and Oni 2007; Zhuang 2009; Maila et al. 2014; Skousen 2014).

Process of metal hydroxide precipitation has many advantages. It is a relatively simple technique, implementation costs are low, and its $\mathrm{pH}$ is easy to control. Although, the process generates large volumes of lowdensity sludge that is difficult to further undergo dewatering (Menezes et al. 2010; Park et al. 2013; Chen et al. 2014; Kim et al. 2014; Seo et al. 2014). Some metal hydroxides are amphoteric, and precipitation of the mixture of metals is a problem, the ideal $\mathrm{pH}$ for one ion can precipitate the other metal back into solution. In addition, complexing agents present in the solution may inhibit metal hydroxide precipitation (Fu and Wang 2011).

\section{Metal Sulfide Precipitation}

Metal sulfide precipitation is also an effective method for removing heavy metal ions. One of the main advantages of using sulfides is the lower solubility of metal compounds than hydroxide precipitates (Table 1) (Wang et al. 2004; Lewis 2010; Fu and Wang 2011; Bejan and Bunce 2015; Malik et al. 2019).

Sulfide precipitates are not amphoteric so it can achieve a high degree of metal removal in a shorter time over a wide $\mathrm{pH}$ range compared with hydroxide precipitation. Precipitated sludge has better settling properties; it is easier to thicken and dewater compared with sludge

Table 1 Theoretical solubilities of hydroxides and sulfides of selected metals in pure water (Wang et al. 2004)

\begin{tabular}{lll}
\hline \multirow{2}{*}{ Metal } & \multicolumn{2}{l}{ Solubility of metal ion $(\mathrm{mg} / \mathrm{L})$} \\
\cline { 2 - 3 } & As hydroxide & As sulfide \\
\hline Cadmium $\left(\mathrm{Cd}^{2+}\right)$ & $2.3 \cdot 10^{-5}$ & $6.7 \cdot 10^{-10}$ \\
Chrome $\left(\mathrm{Cr}^{3+}\right)$ & $8.4 \cdot 10^{-4}$ & No precipitate \\
Cobalt $\left(\mathrm{Co}^{2+}\right)$ & $2.2 \cdot 10^{-1}$ & $1.0 \cdot 10^{-8}$ \\
Copper $\left(\mathrm{Cu}^{2+}\right)$ & $2.2 \cdot 10^{-2}$ & $5.8 \cdot 10^{-13}$ \\
Iron $\left(\mathrm{Fe}^{2+}\right)$ & $8.9 \cdot 10^{-1}$ & $3.4 \cdot 10^{-5}$ \\
Lead $\left(\mathrm{Pb}^{2+}\right)$ & 2.1 & $3.8 \cdot 10^{-9}$ \\
Magnesium $\left(\mathrm{Mn}{ }^{2+}\right)$ & 1.2 & $2.1 \cdot 10^{-3}$ \\
Mercury $\left(\mathrm{Hg}^{2+}\right)$ & $3.9 \cdot 10^{-4}$ & $9.0 \cdot 10^{-2}$ \\
Nickel $\left(\mathrm{Ni}^{2+}\right)$ & $6.9 \cdot 10^{-3}$ & $6.9 \cdot 10^{-8}$ \\
Silver $\left(\mathrm{Ag}^{+}\right)$ & 13.3 & $7.4 \cdot 10^{-12}$ \\
Tin $\left(\mathrm{Sn}^{2+}\right)$ & $1.1 \cdot 10^{-4}$ & $3.8 \cdot 10^{-9}$ \\
Zinc $\left(\mathrm{Zn}^{2+}\right)$ & 1.1 & $2.3 \cdot 10^{-7}$ \\
\hline
\end{tabular}


obtained during hydroxide precipitation (Lewis 2010; Fu and Wang 2011; Bejan and Bunce 2015).

The precipitation of metal sulfides can be carried out using a variety of precipitants, such as sodium sulfide $\left(\mathrm{Na}_{2} \mathrm{~S}\right)$, sodium hydrosulfide (NaHS), calcium sulfide $(\mathrm{CaS})$, barium sulfide $(\mathrm{BaS})$, iron sulfide $(\mathrm{FeS})$, ammonium sulfide $\left(\left(\mathrm{NH}_{4}\right)_{2} \mathrm{~S}\right)$, and sodium thiosulfate $\left(\mathrm{Na}_{2} \mathrm{~S}_{2} \mathrm{O}_{3}\right.$ ) (Lewis 2010; Mokone et al. 2012; Thomas et al. 2014; Bejan and Bunce 2015).

The sulfidation process is similar to the precipitation of metal hydroxides. In order to precipitate metals, sulfide is added and the precipitate is separated from the solution, among others by deposition or gravity filtration (Eqs. 2 and 3) (Wang et al. 2004).

$\mathrm{Na}_{2} \mathrm{~S}+\mathrm{MSO}_{4}=\mathrm{MS}$ (precipitate) $+\mathrm{Na}_{2} \mathrm{SO}_{4}$

$\mathrm{FeS}+\mathrm{Cu}^{2+}=\mathrm{CuS}($ precipitate $)+\mathrm{Fe}^{2+}$

The main factors that influence the sulfide process are $\mathrm{pH}$ and the type of sulfur source (Ke et al. 2014). The reaction also depends on the type and initial metal concentration, the precipitation agent used, and the concentration ratio of the two components (Lewis 2010). Wei and Osseo-Asare (1996) showed that Eh and $\mathrm{pH}$ strongly affected the pyrite formation, with pyrite forming between pH 3.6 and 5.7 and Eh -0.05 to $0.01 \mathrm{~V}$. Stén and Forsling (2000) investigated the lead sulfide precipitation. They found that precipitation conditions (speed of titration) affected the results. When the lead nitrate $(1 \mathrm{~g} / 30 \mathrm{~mL}$, $160 \mathrm{mM}$ ) was very slowly titrated with $0.1 \mathrm{M}$ sodium sulfide, they found that both lead and sulfide adsorbed onto the precipitate surface. Jha et al. (1981) achieved almost a complete precipitation of nickel and cobalt in less than an hour, ensuring proper mixing and a sufficiently high concentration of recycled sludge.

Zinc is often chosen as the model metal for sulfide precipitation studies. On the one hand, the metal is important in the environment; on the other hand, it has only one redox state (II), which simplifies the chemistry. Copper is one of the metals that is difficult to study, due to its ability to reduce in sulfide solutions and as a consequence, the formation of a number of bisulfide, sulfide, and polysulfide complexes (Lewis 2010). The mechanism of metal precipitation is different for individual metal ions and their mixtures. In the case where a metal mixture is precipitated from solution, use of the theoretical solubility values of individual metals is limited (Grabas 2009).

Some early papers describe use of a sulfide in industry. Kim (1981) described two main types of sulfide precipitation:

- $\quad$ soluble sulfide precipitation (SSP) using reagents such as $\mathrm{Na}_{2} \mathrm{~S}$ and $\mathrm{NaHS}$,

- insoluble sulfide precipitation (ISP) using reagents such as $\mathrm{FeS}$ and $\mathrm{CaS}$.

The difference is in how a sulfide ion is introduced into wastewater. In the SSP process, sulfide is added in the form of a water-soluble precipitation agent, and the process can be carried out in a continuous or batch way. In the ISP process, the precipitation agent is introduced in the form of a suspension in which the reagent is slightly dissolved (Kim 1981, US Environmental Protection Agency (US EPA) 2000).

The precipitation of metal sulfides is a difficult method due to the very low solubility of metal sulfides, while the process is highly sensitive to the dosing of the precipitation agent. During the precipitation of metal sulfides, colloidal precipitates are formed, which cause problems in further separation processes. In addition, there is a risk associated with the emission of toxic hydrogen sulfide during the process (Lewis 2010; Fu and Wang 2011). All these limitations have forced to search for new and effective precipitation compounds to improve existing metal precipitation techniques $(\mathrm{Fu}$ et al. 2007a; Thomas et al. 2014).

\subsection{Alternative Methods of Metal Precipitation}

\subsubsection{Chelating Agent Precipitation}

Alternative methods for precipitation of heavy metals from aqueous solutions include precipitation using chelating ligands. Matlock et al. (2002a) in their research determined the effectiveness of use of three widely used commercial reagents for heavy metal binding: potassium/ sodium thiocarbonate (STC), 2,4,6-trimercaptotiazine, trisodium salt nonahydrate (TMT), and sodium dimethyldithiocarbamate (SDTC) (Fig. 2).

STC (Fig. 2a) is a sodium (with or without potassium) thiocarbonate $([\mathrm{Na}, \mathrm{K}] 2 \mathrm{CS} 3 \cdot \mathrm{nH} 2 \mathrm{O}$, where $n \geq 0)$ which has the trade name of Thio-Red. It is a liquid organic compound used to remove heavy metals from process 


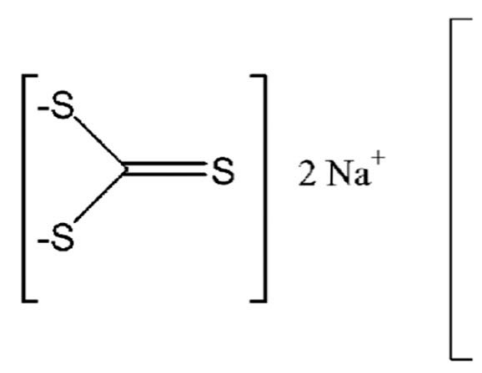

(a)

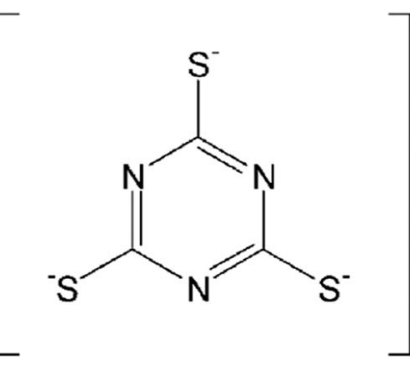

(b)
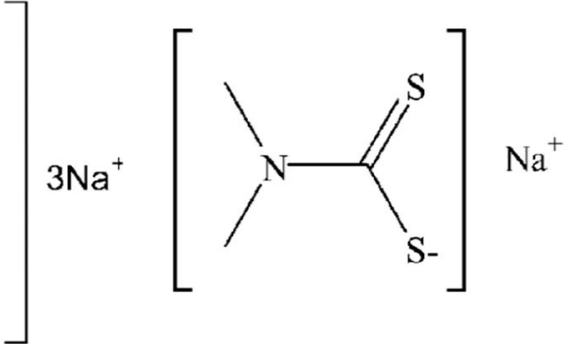

(c)

Fig. 2 (a) Potassium/sodium thiocarbonate (STC); (b) 2,4,6-trimercaptotiazine, trisodium salt nonahydrate (TMT), (c) sodium dimethyldithiocarbamate (SDTC) (Matlock et al. 2002a)

wastewater, groundwater and other polar solvents (WST Water Specialists Technologies LLC 2018).

Henke (1998) examined the possibility of using STC to remove copper, mercury, lead, and cadmium ions. It turned out that the precipitation of metal if followed by the formation of metal sulfide $(\mathrm{CuS}, \mathrm{HgS}, \mathrm{PbS}$, and $\mathrm{ZnS}$ ), instead of metal thiocarbonates (i.e., $\mathrm{CuCS}_{3}$, $\mathrm{HgCS}_{3}, \mathrm{PbCS}_{3}$ and $\mathrm{ZnCS}_{3}$ ) as initially assumed. As a result a carbon disulfide, volatile and toxic liquid, was formed as a byproduct.

Blue et al. (2008) conducted research on use of STC to precipitate mercury from the solution. Use of STC allowed to reduce $\mathrm{Hg}$ concentration to a level below the limit of detection, but after $24 \mathrm{~h}$, mercury concentration increased again. This was confirmed in other studies, which showed that the STC may remove $\mathrm{Hg}$, presumably as a complex of $\mathrm{Hg}(\mathrm{STC})_{2}$, but then the mercury was slowly released back into solution due to the oxidation of sulfur to sulfate (Matlock et al. 2002a; Hutchison and Atwood 2003).

The next compound, TMT-55 (Fig. 2b) -2,4,6trimercaptotriazine, a trisodium salt nonahydrate, which contains three chelating groups (Wang et al. 2012), is in the form of an aqueous solution of sodium thiocarbonate (with or without potassium), sulfides, and other sulfur compounds $\left(\mathrm{Na}_{3} \mathrm{C}_{3} \mathrm{~N}_{3} \mathrm{~S}_{3} \cdot 9 \mathrm{H}_{2} \mathrm{O}\right)$ (Henke 1998). It is commonly used to precipitate the monovalent and divalent metal ions (Henke et al. 1997, Cecconi et al. 2002, Matlock et al. 2002a, information brochure about TMT15 and TMT from Evonik 2018), such as cadmium, copper, mercury, lead, silver, and zinc from water and wastewater (Tarabocchia and Karg 1990; Ayoub et al. 1995; Fogg et al. 1997; Henke et al. 2000; Bailey et al. 2001; Matlock et al. 2001a). It is also used to bond alkaline earth elements (Henke and Atwood 1998; Henke et al. 2001).
Laboratory studies have shown that this compound removes $\mathrm{Cu}, \mathrm{Hg}, \mathrm{Pb}$, and $\mathrm{Zn}$ from aqueous solutions to form stable metal sulfides $(\mathrm{CuS}, \mathrm{HgS}, \mathrm{PbS}$ i $\mathrm{ZnS}$ ) (Henke 1998). The advantages of this product also include limited sludge formation. The disadvantage is high toxicity; high costs of sediment removal; price of the chelating agent; inability to remove trivalent ions such as $\mathrm{Fe}^{3+}, \mathrm{Al}^{3+}$, and $\mathrm{Cr}^{3+}$ (Decostere et al. 2009); and in the case of precipitation of mercury ions, impermanent nature of the TMT-Hg complex is formed (Hutchison et al. 2008).

A commonly used chelating ligand is a sodium thiocarbamate (SDTC), with the trade name HMP-2000 (Fig. 2c). This precipitating agent belongs to the dithiocarbamate group. A major problem associated with this substance is its tendency to decompose into toxic products including tetramethylthiuram and thiuram (Matlock et al. 2002a; Atwood and Zaman 2005).

In practice, producing chelating ligands is simple and economically viable. However, many of the complexing compounds obtained are not specifically designed to bind specific heavy metals. This often leads to unstable metal-ligand bonds, whereby the metals can be released back into the solution (Henke 1998; Henke et al. 2000; Matlock et al. 2001a; 2002a). A disadvantage of using ligands is also the need to use a high dose of a precipitation agent so that the final metal concentration meets the relevant environmental protection requirements (Matlock et al. 2002a).

\subsubsection{Precipitation Using Dithiocarbamate Compounds}

Often used precipitation agents are compounds belonging to the dithiocarbamate group (DTC) (Fig. 3) (Tassel et al. 1997; Andrus 2000; Monser and Adhoum 2002; Yan et al. 2003; Fu et al. 2006a; Fu et al. 2006b; Fu et al. 
2007a, b, Jing et al. 2009; Zhena et al. 2012; Bobinihi et al. 2018). DTCs are obtained via the reaction of carbon bisulfide $\left(\mathrm{CS}_{2}\right)$ and sodium hydroxide $(\mathrm{NaOH})$ with mono-, di-, or poly-amines. The compounds possess single, double, or multiple chelating functional groups to bind with heavy metals (Georgiadisa et al. 2006; Wang et al. 2012). These substances can be divided into two categories: precipitators with macromolecules and compounds with small molecules (Fu et al. 2006a).

Small molecular precipitants are available in two forms: sodium dimethyldithiocarbamate and diethyldithiocarbamate (DDTC) (Andrus 2000; Matlock et al. 2002a; Fu et al. 2006a; Fu et al. 2007b). DTC is added to the solution usually in a stoichiometric ratio, equal to precipitated metals. The insoluble salts formed are co-precipitated to form neutral solid hydroxide, which is then removed from the solution. In practice, DTC compounds are often dosed with a $10 \%$ excess. However, excess DTC can be toxic to bacteria, algae, and other aquatic organisms (Andrus 2000). In addition, it was noted that during precipitation using DTC, insoluble metal complexes such as $\mathrm{Cu}$ (diethyldithiocarbamate) $)_{2}$ may form ( $\mathrm{Fu}$ et al. 2006b). Diethyldithiocarbamate and dimethyldithiocarbamate have only one chelating group (Fu et al. 2006a, Fu et al. 2007b).

In order to improve the efficiency of heavy metal precipitation by DTCs, the number of dithiocarbamate groups is increased. Fu et al. (2006a, 2006b) worked on the use of disodium $\mathrm{N}, \mathrm{N}$-bis-(dithiocarboxy)piperazine $\left(\mathrm{Na}_{2} \mathrm{BDP}\right)$ for precipitation of heavy metals from wastewater. The compound was synthesized by the reaction of piperazine with $\mathrm{CS}_{2}$ and $\mathrm{NaOH}$ in dry ethyl ether and isopropyl alcohol under vigorous stirring over $5 \mathrm{~h}$. The molar ratio used was as follows: piperazine: $\mathrm{CS}_{2}: \mathrm{NaOH}=$ 1:2:2. The raw product was recrystallized from an aqueous solution containing 50\% methanol (Fu et al. 2006a; Fu et al. 2006b; Fu et al. 2007b).

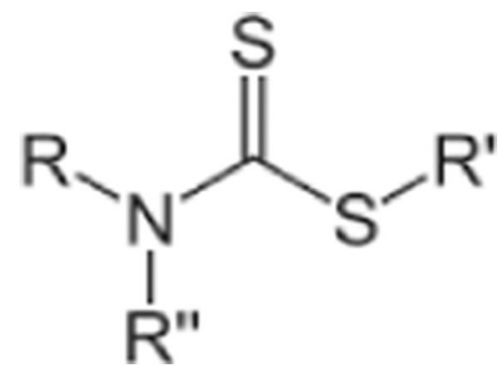

Fig. 3 Chemical structure of dithiocarbamates (https://pubchem. ncbi.nlm.nih.gov/compound/Dithiocarbamate\#section=Top, 2018)
Fu et al. in their research verified the effectiveness of using $\mathrm{Na}_{2} \mathrm{BDP}$ for precipitation of copper ions from wastewater (Fu et al. 2006a) (Fig. 4) and for the simultaneous precipitation of copper ions and Acid Red-37 dye from wastewater (Fu et al. 2006b) (Fig. 5).

The researchers found a relationship between degree of removal of copper ion, and the molar ratio of BDP/ $\mathrm{Cu}^{2+}$. Addition of a dicarbamate compound in a ratio of 1:1 $\left(\mathrm{BDP} / \mathrm{Cu}^{2+}\right)$ allowed reduction of copper from an initial concentration of 50 to $0.04 \mathrm{mg} / \mathrm{L}$. The results showed that the precipitation process can be carried out efficiently over a wide $\mathrm{pH}$ range (4.0-11.0) $(\mathrm{Fu}$ et al. 2006a). Further studies confirmed that $\mathrm{Na}_{2} \mathrm{BDP}$ can simultaneously and effectively remove heavy metal ions and dyes from aqueous solutions (Fu et al. 2006b).

In another work, Fu et al. (2007b) continued research on the use of $\mathrm{Na}_{2} \mathrm{BDP}$ for metal precipitation, this time on the example of sewage containing nickel compounds (Fig. 6). The studies compared the use $N, N$ bis-(dithiocarboxy)piperazine with that of diethyldithiocarbamate (DDTC).

After addition of predetermined dose of BDP or DDTC to an aqueous solution containing $50.00 \mathrm{mg} / \mathrm{L}$ of $\mathrm{Ni}$ (II), efficiency of precipitation was tested colorimetrically using dimethylgloxime. Concentration of nickel (II) ions after the precipitation process using BDP was $0.10 \mathrm{mg} / \mathrm{L}$, at a stoichiometric ratio 1: 1 (BDP: $\mathrm{Ni}^{2+}$ ). In case of DDTC, ensuring the molar ratio of DDTC: $\mathrm{Ni}^{2+}$ at $2: 1$, the final concentration of the tested metal was $0.76 \mathrm{mg} / \mathrm{L}$. It was found that increasing the $\mathrm{pH}$ of solution has a positive effect on the removal of $\mathrm{Ni}$ (II), and this effect is similar for both BDP and DDTC (Fu et al. 2007b).

Sedimentation properties of the resulting sediments were also investigated. After $5 \mathrm{~min}$ of stirring and $1 \mathrm{~min}$ of sediment settling, turbidity of the solution in which BDP was used was 7 NTU, while using DDTC - 93 NTU. For the second precipitation agent, even after $1 \mathrm{~h}$ of sedimentation, the turbidity of the solution was still high and amounted 60 NTU. This indicates that the use of BDP to precipitate nickel ions is characterized by better sedimentation properties of the sludge compared with that of DDTC (Fu et al. 2007b).

In practice, nickel often occurs in the form of complexes in industrial wastewater. Therefore, $\mathrm{Fu}$ et al. (2007b) also investigated the possibility of precipitation of nickel ions in a coordinated form-NiCA. At a stoichiometric BDP:NiCA ratio of 1:1, the final concentration of $\mathrm{Ni}^{2+}$ was $2.38 \mathrm{mg} / \mathrm{L}$. Increasing the BDP dose by $10 \%$ resulted in a decrease of the final concentration to 


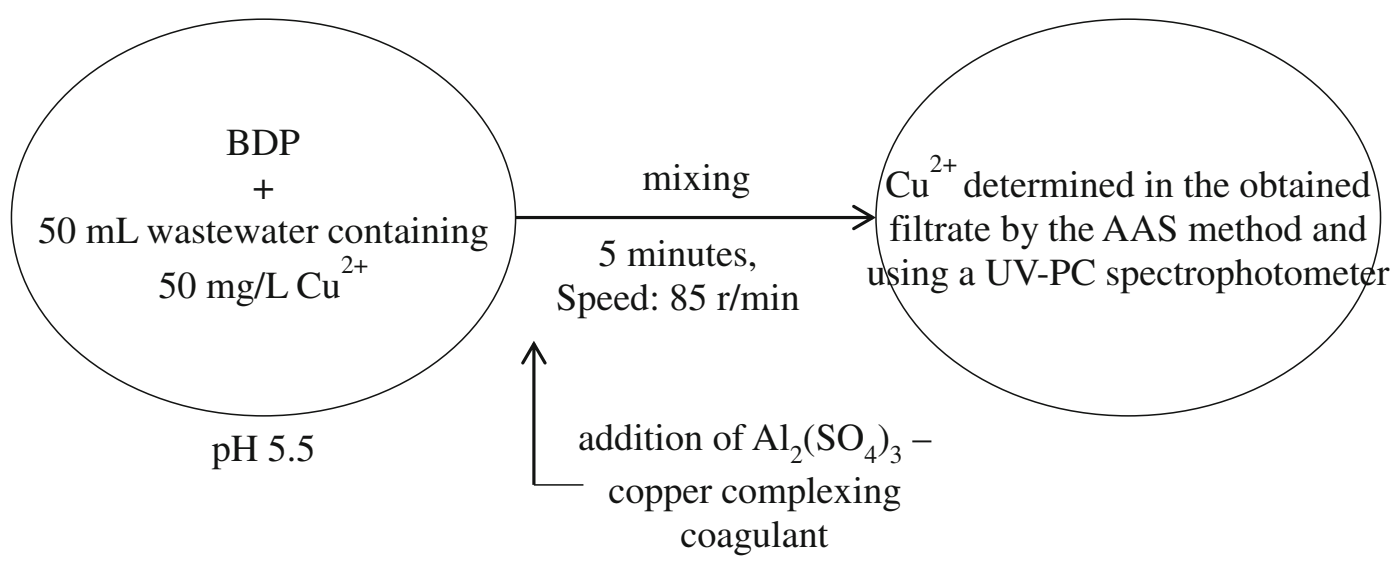

Fig. 4 Diagram of a procedure for removing copper ions from wastewater using $\mathrm{Na}_{2} \mathrm{BDP}$ (Fu et al. 2006a)

$0.08 \mathrm{mg} / \mathrm{L}$. In case of precipitation with DDTC, the final concentration of $\mathrm{Ni}^{2+}$ was $3.12 \mathrm{mg} / \mathrm{L}$, and after increasing the dose of DDTC by $10 \%$, the concentration decreased to $0.30 \mathrm{mg} / \mathrm{L}$. This shows that in the case of precipitation of nickel compounds in the form of complexes, it is necessary to use a slight excess of precipitation agent. Research shows that BDP is a more effective precipitant than DDTC. Using BDP, sedimentation of the precipitate is faster and the precipitation of the nickel ions is more effective than using DDTC. In addition, the BDP may partially remove the dye from the solution, while DDTC does not have such properties.

Another dithiocarbamate-type compound with an increased number of chelating groups is sodium 1,3,5hexahydrotriazinedithiocarbamate (HTDC) $\left(\mathrm{CH}_{2}\right)_{3}$ $\left(N_{C S}\right)_{3}^{3-}$ (Fig. 7) (Fu et al. 2007a; Lu and Astruc 2018).

HDTC was obtained by adding $25-28 \%$ ammonia to $40 \%$ formaldehyde aqueous solution. The mixture was stirred at a temperature below $10{ }^{\circ} \mathrm{C}$ for $30 \mathrm{~min}$, then $\mathrm{CS}_{2}$ and $50 \% \mathrm{Na}_{2} \mathrm{CO}_{3}$ aqueous solution were added.
The resulting solution was again stirred for $5 \mathrm{~h}$ at room temperature $\left(25 \pm 1^{\circ} \mathrm{C}\right)$. The final product was crystallized as a white solid (Fu et al. 2007a).

$\mathrm{Fu}$ et al. (2007a) investigated the possibility of copper precipitation from wastewater with HTDC (Fig. 8). Considering that copper can form complexes in wastewater, e.g., CuEDTA (copper ethylenediaminetetraacetic acid), that will not be precipitated using hydroxide or sulfide, the authors investigated the possibility of precipitation of the complex with the HTDC. The concentration of copper ions in wastewater was tested by atomic absorption spectrometry (AAS), which finally was lower than $0.5 \mathrm{mg} / \mathrm{L}$, confirming the efficacy of HTDC.

\subsubsection{Ligands Designed for Irreversible Binding of Heavy Metals}

In order to create more effective, cheaper, and stable compounds for precipitation of heavy metals, the synthesis of a number of new ligands used for irreversible binding of heavy metals was started. One of such ligand

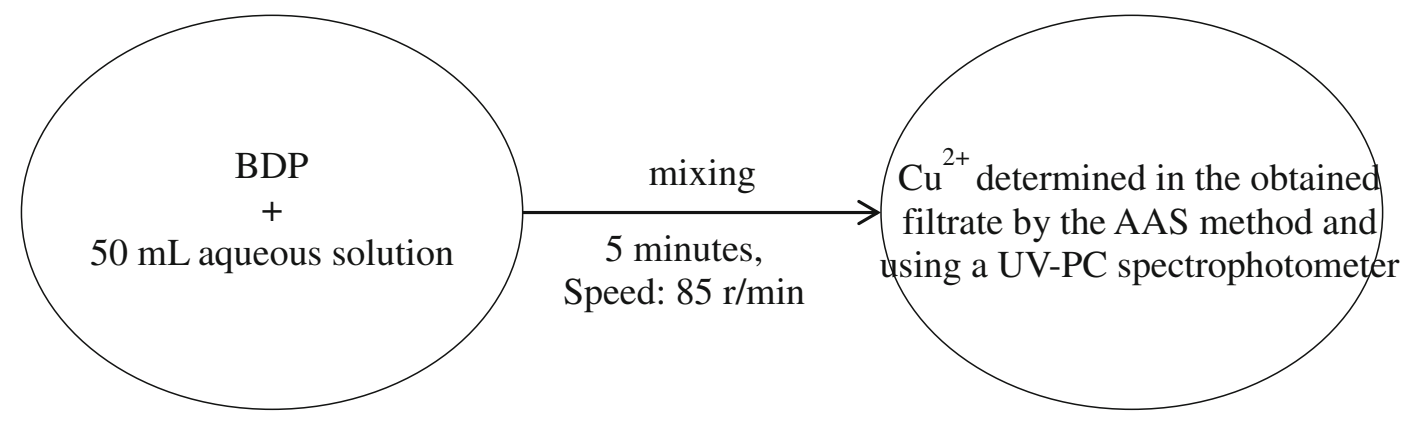

pH 5.5

Fig. 5 Diagram of a procedure for removing copper ions and Acid Red-37 dye from wastewater using $\mathrm{Na}_{2} \mathrm{BDP}$ (Fu et al. 2006b) 


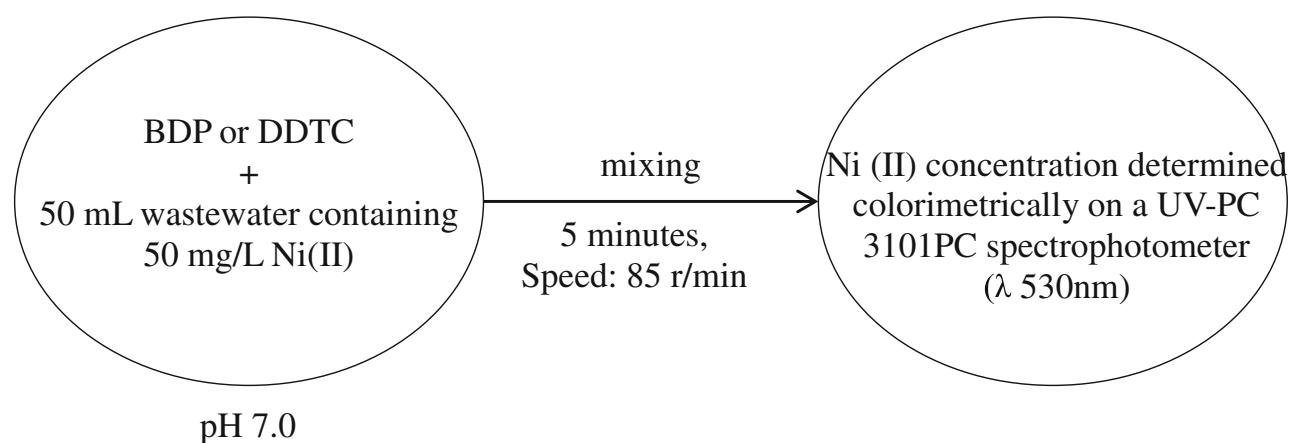

Fig. 6 Nickel removal from wastewater by chemical precipitation using $\mathrm{Na}_{2} \mathrm{BDP}$ (Fu et al. 2007b)

is 2,6-pyridinediamidoethanethiol (PyDET) (Matlock et al. 2002a). Studies on use of this compound to remove heavy metals from the solution show that it effectively binds metals, so that their final concentration is significantly lower than the limits set by US EPA. The precipitated product is insoluble in organic solvents and stable in a wide $\mathrm{pH}$ range from 0 to 14 (Henke et al. 1999; Matlock et al. 2001b; 2001c). When using PyDET, the mercury concentration decreased from 50.00 to $0.09 \mathrm{mg} / \mathrm{L}$ and the lead concentration from 50.00 to $0.05 \mathrm{mg} / \mathrm{L}$ (Matlock et al. 2002a).

The problem of poor metal binding to the precipitant mainly concerns with mercury (Matlock et al. 2003a). This metal easily degrades, which releases it back into the environment (Henke 1998; Matlock et al. 2001a; 2002a). To solve this problem, Matlock et al. (2001c, $2002 \mathrm{~d}, 2003 \mathrm{a}, 2003 \mathrm{~b}$ ) synthesized 1,3benzenediamidoethanethiol $\left(\mathrm{BDETH}_{2}\right)$, which can be used as the alkali salt $\left(\mathrm{BDET}^{2-}\right)$ or the dialkali salt $\mathrm{Na}_{2}$ (BDET) (Fig. 9) for irreversibly binding mercury and lead (Matlock et al. 2001c; 2003a). This compound was designed based on the theory of hard and soft acids and bases (HSAB), which assumes that a soft base (such

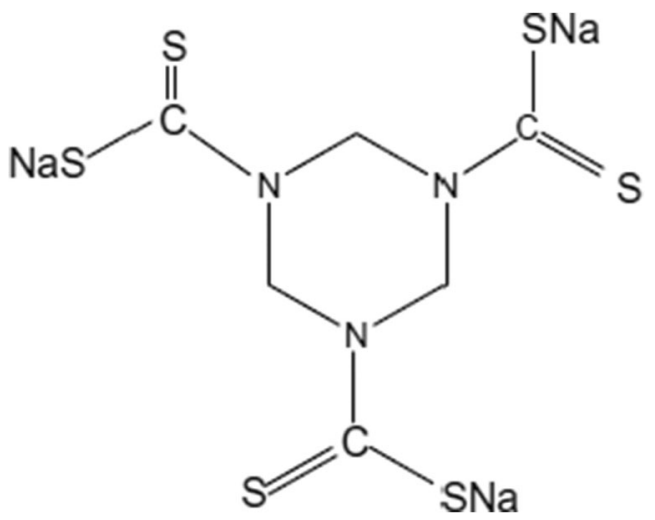

Fig. 7 HTDC chemical structure (Fu et al. 2007a) as disodium $\mathrm{BDETH}_{2}$ ) should favorably interact with and bind to metals that are soft ones such as $\mathrm{Hg}^{2+}$ and $\mathrm{Pb}^{2+}$ (Pearson 1963; Matlock et al. 2001c).

Zaman et al. (2007a) described $\mathrm{BDETH}_{2}$ as an aromatic compound that contains side chains with two terminal thiol-amide arms and binds heavy metals in a linear system. Nitrogen atoms may also be involved in binding, depending on metal coordination preference (Matlock et al. 2002d).

Matlock et al. (2001c) in their study achieved 99.97\% removal of $\mathrm{Hg}^{2+}$ ions (final concentration $0.02 \mathrm{mg} / \mathrm{L}$ ) using a $10 \%$ increased dose of $\mathrm{BDETH}_{2}$ at $\mathrm{pH} 4.0$ and a reaction time of $20 \mathrm{~h}$. In turn, the maximum lead removal in a 6-h reaction at $\mathrm{pH} 4.0$ and 1:1 $\mathrm{M}$ ratio (metal:ligand) was $99.90 \%$ (final concentration $0.05 \mathrm{mg} / \mathrm{L})$.

Further studies showed that $\mathrm{BDETH}_{2}$ as $\mathrm{BDET}^{2-}$ can bind elemental mercury, but much slower than $\mathrm{Hg}^{2+}$ ions. Using a $10 \%$ higher dose of $\mathrm{BDET}^{2-}$ than the calculated molar dose, a 93\% mercury loss was found. Increasing the $\mathrm{BDET}^{2-}$ dose to $140 \%$ resulted in the precipitation of $99 \%$ mercury from the solution. It was found that higher ligand dose results in lower mercury concentration (Matlock et al. 2003a). BDET (the MetX trade name) was used in other numerous studies: to remove mercury from wastewater from gold mining (Matlock et al. 2002b; 2002c), to remove various heavy metals from acid leachate from mine (Matlock et al. 2002d; Chusuei et al. 2008), to reduce the leaching of metals from minerals (Matlock et al. 2003b; Atwood and Zaman 2005; Zaman et al. 2007b), to remove lead from the leachate from accumulators in which its concentration was from 2 to $300 \mathrm{mg} / \mathrm{L}$, at a $\mathrm{pH}$ of about 1.5 (Matlock et al. 2002e), for removing mercury from soil (Matlock et al. 2003a) and for low level mercury removal from aqueous solutions (Blue et al. 2010). Numerous studies have shown that the precipitate formed with 


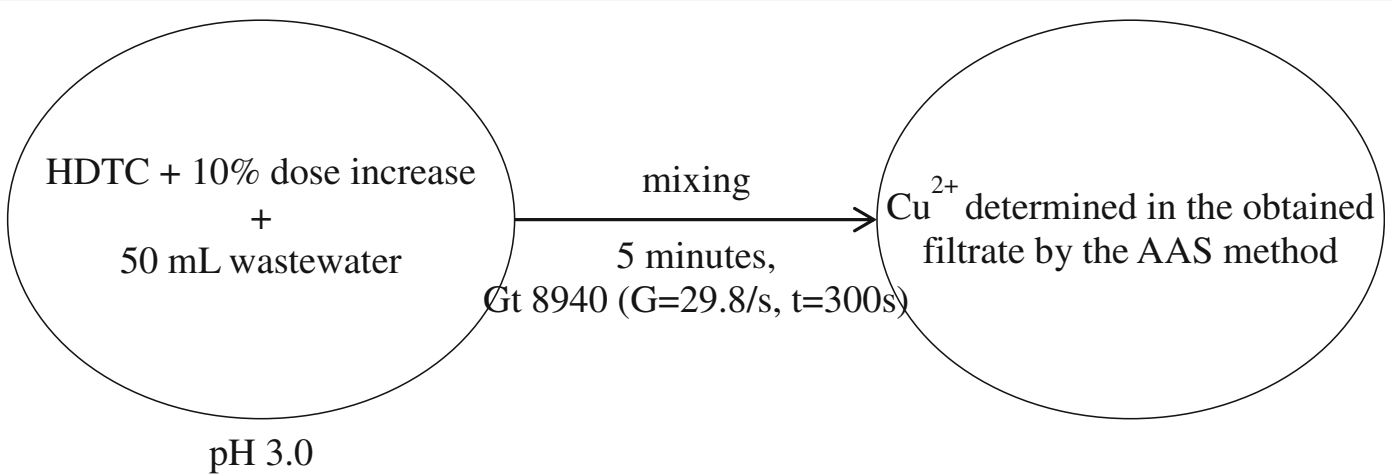

Fig. 8 Diagram of a procedure for removing copper ions from wastewater using HDTC (Fu et al. 2007a)

BDET is insoluble in water in commonly used organic solvents stable in a wide $\mathrm{pH}$ range from 0.0 to 14.0 (Matlock et al. 2001c, 2002b, d, 2003a, c).

The dipotassium salt of 1,3-benzendiamidoethanethiol $\left(\mathrm{K}_{2} \mathrm{BDET}\right)$ is effective in removing "soft" heavy metals such as $\mathrm{Hg}, \mathrm{Cd}, \mathrm{Cu}$, and $\mathrm{Pb}$ in the range from 10 to $100 \mathrm{mg} / \mathrm{L}$ (Matlock et al. 2001c; Atwood et al. 2003). Blue et al. (2008) used $\mathrm{K}_{2} \mathrm{BDET}$ to precipitate mercury in low concentrations from groundwater. Fifteen minutes after the addition of $\mathrm{K}_{2} \mathrm{BDET}$, the $\mathrm{Hg}$ concentration was reduced to a level below the CVAF detection limit of $0.05 \mu \mathrm{g} / \mathrm{L}$. It was found that mercury is preferentially bound by the precipitating agent; however, when the ligand is in excess, it also has the ability to bind other divalent metals. The order of binding divalent metals with BDET is $\mathrm{Hg}, \mathrm{Pb}, \mathrm{Cd}$, $\mathrm{Ni}$, and Zn (Matlock et al. 2003c; Blue et al. 2008).

Another group of complex compounds used for the stable precipitation of heavy metals is the pyridinebased thiol ligands (DTPY) which utilizes two chains at the 2,6-position, consisting of three carbons, one nitrogen, and two sulfur end groups (Fig. 10). A stable complex is obtained through multiple interactions between a divalent metal cation and sulfur and nitrogen atoms in the ligand (Matlock et al. 2001b).

A ligand of this type allows for stronger precipitation of heavy metals through the use of a tetrahedral bonding arrangement around a central metal atom. Current research lists mercury, cadmium, copper, and lead as metals that can be successfully precipitated using DTPY (Matlock et al. 2001b).

Hutchison et al. (2008) investigated use of ligands for mercury binding in tetrahedral geometry. These compounds consisted of alkyl groups, and not aromatic groups, as in other studies, which resulted in very high flexibility of the substance and enabled tetrahedral geometry around $\mathrm{Hg}$. It is described that each of these compounds has a three or four carbon backbone with a sulfide group on both ends and a two to four carbon alkyl arm attached to each sulfide, with each arm ending in a thiol group (Fig. 11).

Four compounds containing successively 3 sulfur atoms and 2 thiol groups, 3 sulfur atoms and 3 thiol groups, 3 sulfur atoms and 4 thiol groups, 4 sulfur atoms and 4 thiol groups were synthesized. A key feature of these ligands was to ensure the binding of mercury ions to many sulfur atoms, thereby reducing its solubility in water. The obtained degree of mercury removal from the solution, using this group, was comparable with the efficiency of precipitation using aromatic chelates, and the mercury ligands precipitated were of a stable nature (Hutchison et al. 2008).

Table 2 summarizes and compares the efficiency of removal of selected metals by sulfur-containing

Fig. 9 BDET $^{2-}$ structure (Matlock et al. 2003a)

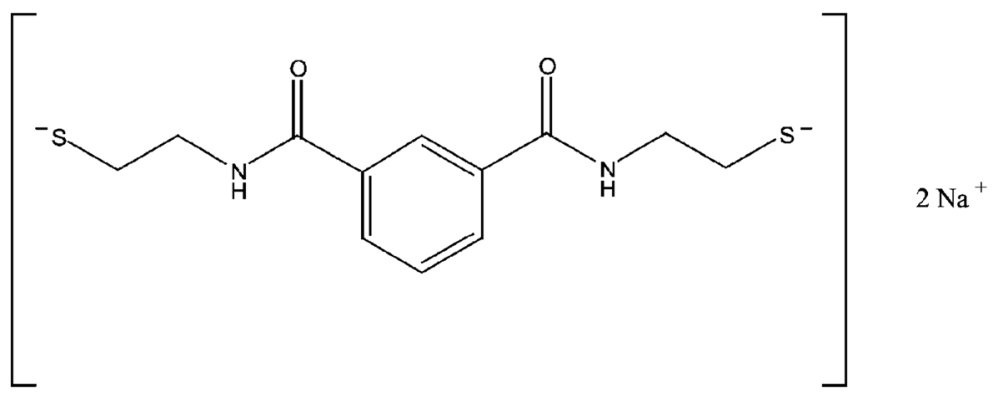


Fig. 10 Chemical structure of DTPY (Matlock et al. 2001b)

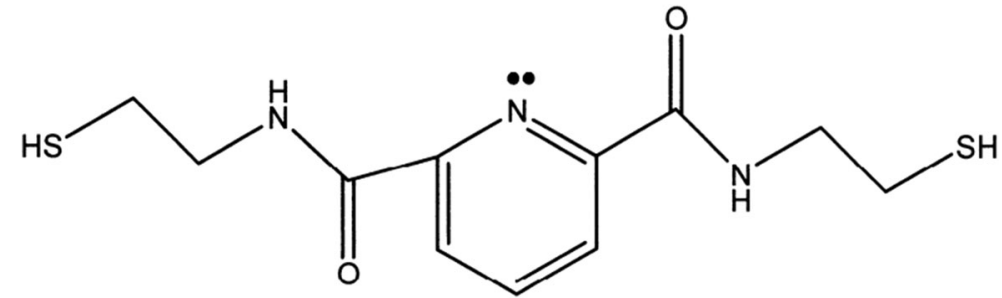

precipitation compounds described in the article. The table shows that depending on the type of precipitating agents and the conditions of the precipitation process, the efficiency of metal removal from the solution may be different. The lowest efficiency of metal precipitation was noted for chelating ligands (STC, TMT, SDTC) and for diethyldithiocarbamate (DDTC). With the increase of dithiocarbamate groups in the molecule, the efficiency of metal precipitation improves. And so is the case of HTDC (dithiocarbamate-type compound with an increased number of chelating groups) for which the efficiency of removing copper from the solution was over $99 \%$. Over $90 \%$ efficiency of metal precipitation was also noted in the case of 2,6-pyridinediamidoethanethiol (PyDET) and 1,3-benzenediamidoethanethiol $\left(\mathrm{BDETH}_{2}\right)$ and its salts: the alkali salt $\left(\mathrm{BDET}^{2-}\right)$ and the dipotassium salt $\left(\mathrm{K}_{2} \mathrm{BDET}\right)$. Additionally, using a higher dose of precipitant agent than the calculated molar dose results in better efficiency in removing metals from solutions. Generally, the trend is to use more effective, cheaper, and stable precipitating agents in a dose that does not interfere with the process.

\section{Summary}

1 One of the most commonly used methods for removing heavy metals from water and wastewater is chemical precipitation using hydroxides or sulfides. The process is characterized by simplicity and low costs. However, during the precipitation of metal hydroxides, large amounts of precipitate are formed, metal hydroxides are amphoteric compounds, and the precipitated metal can go back into the solution.

2 Advantages of precipitation using sulfides include a higher degree of metal reduction in a shorter time (associated with lower solubility of metal compounds in form of sulfides compared with metal hydroxides) over a wide $\mathrm{pH}$ range.

3 The disadvantages of chemical precipitation of metal sulfides are low solubility of metal sulfides, high sensitivity of the process to the dosing of the precipitation agent, and the emission of toxic hydrogen sulfide during the process.

4 Improvement of precipitation efficiency is obtained by using an increased dose of precipitation agent.

5 Toxic byproducts are often produced. In the case of STC, it is carbon disulfide. In turn, use of SDTC leads to the formation of tetramethylthiuram and thiuram, a toxic compound classified as biocide.

6 Dithiocarbamate compounds are often used. However, precipitated complexes are usually unstable, and the excessive dose of DTC that is necessary in the process may be toxic to bacteria, algae, and other aquatic organisms.

7 In order to improve the efficiency of heavy metal precipitation, number of dithiocarbamate groups is
Fig. 11 Open-chain ligands containing many sulfur atoms (Hutchison et al. 2008)

Table 2 Efficiency of removal of selected heavy metals by sulfur-containing precipitation agents

\begin{tabular}{|c|c|c|c|c|c|c|}
\hline Precipitant & Metal & $\begin{array}{l}\text { Initial } \\
\text { concentration } \\
(\mathrm{mg} / \mathrm{L})\end{array}$ & $\begin{array}{l}\text { Removal } \\
\text { efficiency } \\
(\%)\end{array}$ & Conditions & Analytical method & Reference \\
\hline \multirow[t]{6}{*}{ STC } & $\mathrm{Pb}$ & 50.00 & $\begin{array}{l}23.52 / 32.66 \\
10.34 / 16.90 \\
3.66 / 4.02\end{array}$ & $\begin{array}{c}1 \mathrm{~h} \text {, stoichiometric } \\
\text { dose } /+10 \% \text { dose } \\
6 \mathrm{~h} \text {, stoichiometric } \\
\text { dose } /+10 \% \text { dose } \\
20 \mathrm{~h}, \text { stoichiometric } \\
\text { dose } /+10 \% \text { dose }\end{array}$ & ICP - OES & $\begin{array}{l}\text { Matlock et al. } \\
2002 \mathrm{a}\end{array}$ \\
\hline & $\mathrm{Cu}$ & 50.00 & $\begin{array}{l}44.46 / 45.84 \\
42.02 / 48.46 \\
42.28 / 46.42\end{array}$ & $\begin{array}{c}1 \mathrm{~h} \text {, stoichiometric } \\
\text { dose } /+10 \% \text { dose } \\
6 \mathrm{~h} \text {, stoichiometric } \\
\text { dose } /+10 \% \text { dose } \\
20 \mathrm{~h}, \text { stoichiometric } \\
\text { dose } /+10 \% \text { dose }\end{array}$ & ICP - OES & \\
\hline & $\mathrm{Cd}$ & 50.00 & $\begin{array}{l}31.24 / 45.82 \\
20.9430 .26 \\
5.86 / 17.00\end{array}$ & $\begin{array}{c}1 \mathrm{~h} \text {, stoichiometric } \\
\text { dose } /+10 \% \text { dose } \\
6 \mathrm{~h} \text {, stoichiometric } \\
\text { dose } /+10 \% \text { dose } \\
20 \mathrm{~h}, \text { stoichiometric } \\
\text { dose }+10 \% \text { dose }\end{array}$ & ICP - OES & \\
\hline & $\mathrm{Fe}$ (II) & 50.00 & $\begin{array}{l}29.70 / 30.42 \\
31.24 / 30.88 \\
34.04 / 32.88\end{array}$ & $\begin{array}{c}1 \mathrm{~h}, \text { stoichiometric } \\
\text { dose } /+10 \% \text { dose } \\
6 \mathrm{~h} \text {, stoichiometric } \\
\text { dose } /+10 \% \text { dose } \\
20 \mathrm{~h}, \text { stoichiometric } \\
\text { dose } /+10 \% \text { dose }\end{array}$ & ICP - OES & \\
\hline & $\mathrm{Hg}$ & 50.00 & $\begin{array}{l}82.82 / 86.56 \\
83.86 / 89.60 \\
86.30 / 92.06\end{array}$ & $\begin{array}{c}1 \mathrm{~h}, \text { stoichiometric } \\
\text { dose } /+10 \% \text { dose } \\
6 \mathrm{~h} \text {, stoichiometric } \\
\text { dose } /+10 \% \text { dose } \\
20 \mathrm{~h}, \text { stoichiometric } \\
\text { dose } /+10 \% \text { dose }\end{array}$ & CVAF & \\
\hline & $\mathrm{Hg}$ & 0.656 & $\begin{array}{c}\text { final conc }< \\
\text { LOD } \\
\text { final conc }< \\
\text { LOD } \\
93.10 \\
86.60 \\
\text { final conc }< \\
\text { LOD } \\
\text { final conc }< \\
\text { LOD } \\
97.00 \\
93.30\end{array}$ & $\begin{array}{l}15 \mathrm{~min}, \mathrm{pH} 4.7 \\
24 \mathrm{~h}, \mathrm{pH} 4.7 \\
120 \mathrm{~h}, \mathrm{pH} 4.7 \\
240 \mathrm{~h}, \mathrm{pH} 4.7\end{array}$ & $\begin{array}{l}\text { CVAF } \\
\text { LOD } 0.05 \mathrm{mg} / \mathrm{L} \text { for } \mathrm{Hg}\end{array}$ & Blue et al. 2008 \\
\hline \multirow[t]{3}{*}{ TMT-55 } & $\mathrm{Pb}$ & 50.00 & $\begin{array}{l}63.58 / 67.88 \\
63.00 / 66.84 \\
57.90 / 65.38\end{array}$ & $\begin{array}{c}1 \mathrm{~h}, \text { stoichiometric } \\
\text { dose } /+10 \% \text { dose } \\
6 \mathrm{~h} \text {, stoichiometric } \\
\text { dose } /+10 \% \text { dose } \\
20 \mathrm{~h}, \text { stoichiometric } \\
\text { dose } /+10 \% \text { dose }\end{array}$ & ICP - OES & $\begin{array}{l}\text { Matlock et al. } \\
2002 \mathrm{a}\end{array}$ \\
\hline & $\mathrm{Cu}$ & 50.00 & $\begin{array}{l}67.64 / 67.62 \\
73.40 / 71.58 \\
79.74 / 74.82\end{array}$ & $\begin{array}{c}1 \mathrm{~h}, \text { stoichiometric } \\
\text { dose } /+10 \% \text { dose } \\
6 \mathrm{~h} \text {, stoichiometric } \\
\text { dose } /+10 \% \text { dose } \\
20 \mathrm{~h}, \text { stoichiometric } \\
\text { dose } /+10 \% \text { dose }\end{array}$ & ICP - OES & \\
\hline & $\mathrm{Cd}$ & 50.00 & $25.72 / 57.92$ & & ICP - OES & \\
\hline
\end{tabular}


Table 2 (continued)

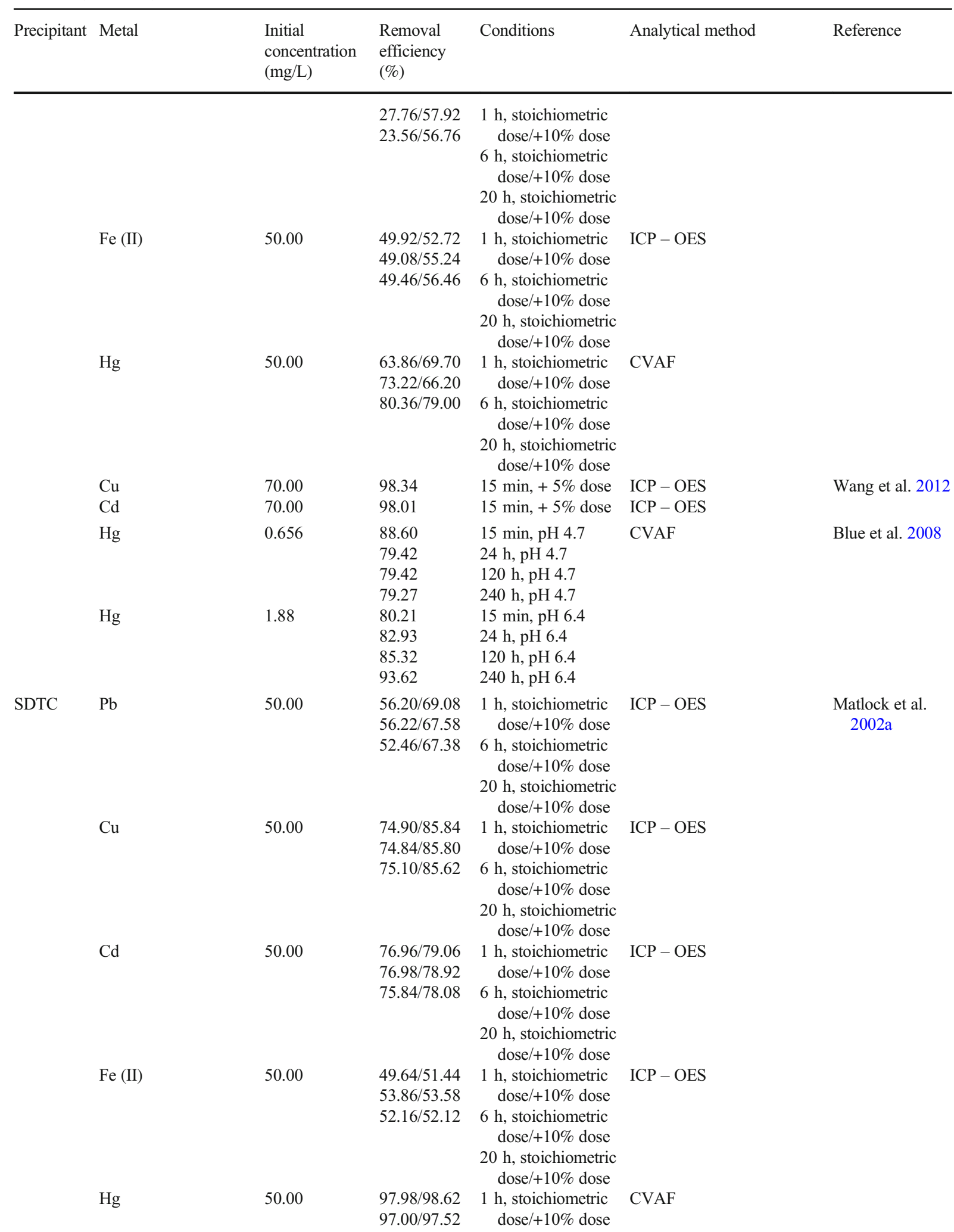


Table 2 (continued)

\begin{tabular}{|c|c|c|c|c|c|c|}
\hline Precipitant & Metal & $\begin{array}{l}\text { Initial } \\
\text { concentration } \\
(\mathrm{mg} / \mathrm{L})\end{array}$ & $\begin{array}{l}\text { Removal } \\
\text { efficiency } \\
(\%)\end{array}$ & Conditions & Analytical method & Reference \\
\hline & & & $94.44 / 96.74$ & $\begin{array}{c}6 \mathrm{~h} \text {, stoichiometric } \\
\text { dose } /+10 \% \text { dose } \\
20 \mathrm{~h}, \text { stoichiometric } \\
\text { dose } /+10 \% \text { dose }\end{array}$ & & \\
\hline & $\mathrm{Hg}$ & 0.656 & 88.70 & $15 \min , \mathrm{pH} 4.7$ & CVAF & Blue et al. 2008 \\
\hline & & & 89.56 & $24 \mathrm{~h}, \mathrm{pH} 4.7$ & & \\
\hline & & & 90.38 & 120 h, pH 4.7 & & \\
\hline & & & 91.52 & 240 h, pH 4.7 & & \\
\hline & $\mathrm{Hg}$ & 1.88 & 85.00 & 15 min, pH 6.4 & & \\
\hline & & & 90.37 & 24 h, pH 6.4 & & \\
\hline & & & 91.86 & 120 h, pH 6.4 & & \\
\hline & & & 94.04 & 240 h, pH 6.4 & & \\
\hline \multirow[t]{15}{*}{ DDTC } & $\mathrm{Cd}$ & 4.00 & 0.00 & pH 3.00 & AAS & Abu-El-Halawa \\
\hline & & & 86.72 & pH 5.30 & & and Zabin \\
\hline & & & 65.70 & $\mathrm{pH} 7.30$ & & 2017 \\
\hline & $\mathrm{Pb}$ & 5.00 & 88.82 & pH 3.00 & & \\
\hline & & & 45.94 & pH 5.30 & & \\
\hline & & & 51.18 & $\mathrm{pH} 7.30$ & & \\
\hline & $\mathrm{Zn}$ & 5.00 & 75.20 & $\mathrm{pH} 3.00$ & & \\
\hline & & & 50.14 & pH 5.30 & & \\
\hline & & & 70.46 & $\mathrm{pH} 7.30$ & & \\
\hline & $\mathrm{Cu}$ & 5.00 & 98.00 & pH 3.00 & & \\
\hline & & & 95.42 & pH 5.30 & & \\
\hline & & & 98.42 & pH 7.30 & & \\
\hline & $\mathrm{Ni}$ (II) & 50.00 & 98.48 & $\begin{array}{l}\text { A ratio 2:1 (DDTC: } \\
\text { Ni2+) }\end{array}$ & $\begin{array}{l}\text { UV-PC spectrophotometer, } \\
\text { the wavelength } 530 \mathrm{~nm}\end{array}$ & Fu et al. $2007 b$ \\
\hline & $\begin{array}{l}\text { NiCA (nickel ions in a } \\
\text { coordinated form) }\end{array}$ & 50.00 & 93.76 & $\begin{array}{l}\text { A ratio } 1: 1 \\
\quad \text { (DDTC:NiCA) }\end{array}$ & & \\
\hline & $\begin{array}{l}\text { NiCA (nickel ions in a } \\
\text { coordinated form) }\end{array}$ & 50.00 & 99.40 & $\begin{array}{l}+10 \% \text { dose of } \\
\text { DDTC }\end{array}$ & & \\
\hline \multirow[t]{3}{*}{ HTDC } & $\mathrm{Cu}$ & 25.00 & 99.00 & $5 \mathrm{~min}, \mathrm{pH} 3.0$ & AAS & Fu et al. 2007a \\
\hline & & 50.00 & 99.30 & & & \\
\hline & & 100.00 & 99.60 & & & \\
\hline \multirow[t]{4}{*}{ BDP } & $\mathrm{Cu}$ & 50.00 & 99.92 & $\begin{array}{l}\text { A ratio } 1: 1 \\
\qquad\left(\mathrm{BDP} / \mathrm{Cu}^{2+}\right)\end{array}$ & $\begin{array}{l}\text { AAS and UV-PC spectro- } \\
\text { photometer }\end{array}$ & Fu et al. 2006a \\
\hline & Ni (II) & 50.00 & 99.80 & $\begin{array}{l}\text { A ratio } 1: 1 \\
\left(\mathrm{BDP}: \mathrm{Ni}^{2+}\right) \\
\text { neutral } \mathrm{pH}\end{array}$ & $\begin{array}{l}\text { UV-PC spectrophotometer, } \\
\text { the wavelength } 530 \mathrm{~nm}\end{array}$ & Fu et al. $2007 b$ \\
\hline & $\begin{array}{l}\text { NiCA (nickel ions in a } \\
\text { coordinated form) }\end{array}$ & 50.00 & 95.24 & $\begin{array}{l}\text { A ratio } 1: 1 \\
\quad(\mathrm{BDP}: \mathrm{NiCA})\end{array}$ & & \\
\hline & $\begin{array}{l}\text { NiCA (nickel ions in a } \\
\text { coordinated form) }\end{array}$ & 50.00 & 99.84 & $+10 \%$ dose of $\mathrm{BDP}$ & & \\
\hline \multirow[t]{2}{*}{ PyDET } & $\mathrm{Hg}$ & 50.00 & 99.82 & - & CVAF & \multirow{2}{*}{$\begin{array}{l}\text { Matlock et al. } \\
2002 \mathrm{a}\end{array}$} \\
\hline & $\mathrm{Pb}$ & 50.00 & 99.00 & - & ICP-OES & \\
\hline \multirow[t]{3}{*}{$\mathrm{BDETH}_{2}$} & $\mathrm{Hg}$ & 60.00 & 99.97 & $\begin{array}{c}+10 \% \text { dose of } \\
\text { BDETH }_{2}, \\
\text { pH 4.0, } 20 \mathrm{~h}\end{array}$ & CVAF & $\begin{array}{l}\text { Matlock et al. } \\
\text { 2001c }\end{array}$ \\
\hline & $\mathrm{Pb}$ & 50.00 & 99.90 & $\begin{array}{l}\text { A ratio 1:1 (metal: } \\
\text { ligand) }\end{array}$ & ICP-OES & \\
\hline & & & & $\mathrm{pH} 4.0,6 \mathrm{~h}$ & \multirow{3}{*}{ CVAF } & \multirow{3}{*}{$\begin{array}{l}\text { Matlock et al. } \\
\text { 2002b }\end{array}$} \\
\hline \multirow{2}{*}{$\mathrm{BDET}^{2-}$} & $\mathrm{Hg}$ & 34.5 & 99.96 & $10 \mathrm{~min}$ & & \\
\hline & $\mathrm{Hg}$ & 34.5 & 99.98 & $15 \min$ & & \\
\hline
\end{tabular}


Table 2 (continued)

\begin{tabular}{|c|c|c|c|c|c|c|}
\hline Precipitant & Metal & $\begin{array}{l}\text { Initial } \\
\text { concentration } \\
(\mathrm{mg} / \mathrm{L})\end{array}$ & $\begin{array}{l}\text { Removal } \\
\text { efficiency } \\
(\%)\end{array}$ & Conditions & Analytical method & Reference \\
\hline \multirow{3}{*}{$\mathrm{K}_{2} \mathrm{BDET}$} & \multirow{3}{*}{$\mathrm{Hg}$} & $\begin{array}{l}50.00 \\
50.00\end{array}$ & $\begin{array}{l}93.00 \\
99.99\end{array}$ & $\begin{array}{l}+10 \% \text { dose of } \\
\text { BDET }^{2-} \\
+40 \% \text { dose of } \\
\text { BDET }^{2-}\end{array}$ & CVAF & $\begin{array}{l}\text { Matlock et al. } \\
\text { 2003a }\end{array}$ \\
\hline & & 0.656 & $\begin{array}{l}\text { final conc }< \\
\text { LOD }\end{array}$ & $\begin{array}{l}15 \mathrm{~min}, 24 \mathrm{~h}, \\
120 \mathrm{~h}, 240 \mathrm{~h}, \\
\mathrm{pH} 4.7\end{array}$ & \multirow[t]{2}{*}{$\begin{array}{l}\text { CVAF } \\
\text { LOD } 0.05 \mathrm{mg} / \mathrm{L} \text { for } \mathrm{Hg}\end{array}$} & \multirow[t]{2}{*}{ Blue et al. 2008} \\
\hline & & 1.88 & $\begin{array}{l}\text { final conc }< \\
\text { LOD }\end{array}$ & $\begin{array}{l}15 \mathrm{~min}, 24 \mathrm{~h}, \\
120 \mathrm{~h}, 240 \mathrm{~h} \\
\mathrm{pH} 6.4\end{array}$ & & \\
\hline
\end{tabular}

final conc $<L O D$ final concentration below the limit of detection, $I C P-O E S$ inductively coupled plasma - optical emission spectrometers, $C V A F$ cold vapor atomic fluorescence, $A A S$ atomic absorption spectrometry

increased. In this way, compounds disodium $N, N$ bis-(dithiocarboxy)piperazine $\left(\mathrm{Na}_{2} \mathrm{BDP}\right)$ and sodium 1,3,5-hexahydrotriazinedithiocarbamate (HTDC) were obtained.

$8 \mathrm{Na}_{2} \mathrm{BDP}$ and HTDC effectively precipitated not only heavy metal ions but also dyes and some complex compounds such as CuEDTA. In addition, when compared with single-chelating dithiocarbamate, better sedimentation properties of the sludge were obtained.

9 Compounds containing thiol groups, such as 1,3benzenediamidoethanethiol $\left(\mathrm{BDETH}_{2}\right), 2,6$ pyridinediamidoethanethiol (PyDET), a pyridinebased thiol ligand (DTPY), or open-chain ligands containing many sulfur atoms, capable of forming tetraadric mercury compounds, are also successfully used for metal precipitation.

10 The dipotassium salt of 1,3-benzendiamidoethanethiol $\left(\mathrm{K}_{2} \mathrm{BDET}\right)$ can be used to remove "soft" heavy metals such as $\mathrm{Hg}, \mathrm{Cd}, \mathrm{Cu}$, and $\mathrm{Pb}$, in the concentration range from 10 to $100 \mathrm{mg} / \mathrm{L}$.

Open Access This article is licensed under a Creative Commons Attribution 4.0 International License, which permits use, sharing, adaptation, distribution and reproduction in any medium or format, as long as you give appropriate credit to the original author(s) and the source, provide a link to the Creative Commons licence, and indicate if changes were made. The images or other third party material in this article are included in the article's Creative Commons licence, unless indicated otherwise in a credit line to the material. If material is not included in the article's Creative Commons licence and your intended use is not permitted by statutory regulation or exceeds the permitted use, you will need to obtain permission directly from the copyright holder. To view a copy of this licence, visit http://creativecommons.org/licenses/by/4.0/.

\section{References}

Abu-El-Halawa, R., \& Zabin, S. (2017). Removal efficiency of Pb, $\mathrm{Cd}, \mathrm{Cu}$ and $\mathrm{Zn}$ from polluted water using dithiocarbamate ligands. Journal of Taibah University for Science, 11, 57-65. https://doi.org/10.1016/j.jtusci.2015.07.002.

Andrus, M. E. (2000). A review of metal precipitation chemicals for metal finishing applications. Metal Finishing, 11, 20-23. https://doi.org/10.1016/S0026-0576(00)83532-1.

Atwood, D. A., Zaman, M. K. (2005). Mercury removal from water, In Atwood, D.A (Ed.) Recent Developments In Mercury Science (pp. 163-182). Berlin, Heidelberg: Springer. https://doi.org/10.1007/11495147.

Atwood, D. A., Matlock, M. M., Howerton, B. S. (2003). Novel multidentate sulfur-containing ligands. United States Patent No. US 6,586, 600 B2, July 1, 2003.

Ayoub, G. M., Koopman, B., Bitton, G., \& Riedesel, K. (1995). Heavy metal detoxification by trimercapto-s-triazine (TMT) as evaluated by a bacterial enzyme assay. Enviromental Toxicology and Chemistry, 14(2), 193-196. https://doi. org/10.1002/etc.5620140202

Bailey, J. R., Hatfield, M. J., Henke, K. R., Krepps, M. K., Morris, J. L., Otieno, T., Simonetti, E. A., Wall, E., \& Atwood, D. A. (2001). Transition metal complexes of 2,4,6-trimercapto-1,3, 5-triazine (TMT): potential precursors to nanoparticulate metal sulfides. Journal of Organometallic Chemistry, 623(1-2), 185-190. https://doi.org/10.1016/S0022-328X(00 )00740-3.

Barakat, M. A. (2011). New trends in removing heavy metals from industrial wastewater. Arabian Journal of Chemistry, 4, 361377. https://doi.org/10.1016/j.arabjc.2010.07.019.

Barbusiński, K., \& Nocoń, W. (2011). Heavy metal compounds in the bottom sediments of the river Klodnica (Upper Silesia). Ochrona Środowiska, 33(1), 13-17. 
Bejan, D., \& Bunce, N. J. (2015). Acid mine drainage: electrochemical approaches to prevention and remediation of acidity and toxic metals. Journal of Applied Electrochemistry, 45, 1239-1254. https://doi.org/10.1007/s10800-015-0915-z.

Blue, L. Y., Van Aelstyn, M. A., Matlock, M. M., \& Atwood, D. A. (2008). Low-level mercury removal from groundwater using a synthetic chelating ligand. Water Research, 42(89), 2025-2028. https://doi.org/10.1016/j. watres.2007.12.010.

Blue, L. Y., Jana, P., \& Atwood, D. A. (2010). Aqueous mercury precipitation with the synthetic dithiolate, $\mathrm{BDTH}_{2}$. Fuel, 89(6), 1326-1330.

Bobinihi, F., Osuntokun, J., \& Onwudiwe, D. (2018). Syntheses and characterization of nickel(II) dithiocarbamate complexes containing $\mathrm{NiS}_{4}$ and $\mathrm{NiS}_{2} \mathrm{PN}$ moieties: nickel sulphide nanoparticles from a single source precursor. Journal of Saudi Chemical Society, 22(4), 381-395. https://doi.org/10.1016/j. jscs.2017.10.001.

Cecconi, F., Ghilardi, C. A., Midollini, S., \& Orlandini, A. (2002). Organomercury derivatives of the 2,4,6-trimercaptotriazine $\left(\mathrm{H}_{3} \mathrm{TMT}\right)$. X-ray crystal structure of $(\mathrm{HgMe})_{3}(\mathrm{TMT})$. Journal of Organometallic Chemistry, 645(1-2), 101-104. https://doi.org/10.1016/S0022-328X(01)01372-9.

Chen, T., Yan, B., Lei, C., \& Xiao, X. (2014). Pollution control and metal resource recovery for acid mine drainage. Hydrometallurgy, 147-148, 112-119. https://doi. org/10.1016/j.hydromet.2014.04.024.

Chusuei, C. C., Zaman, K. M., \& Atwood, D. A. (2008). Charge transfer between benzene-1,3- diamidoethanethiol (BDET) and metal sulfides affect efficiency of acid mine drainage treatment. Colloids and Surfaces A: Physicochemical and Engineering Aspects, 331(3), 155-161. https://doi. org/10.1016/j.colsurfa.2008.07.048.

Decostere, B., Hogie, J., Dejans, P., \& Van Hulle, S. (2009). Removal of heavy metals occurring in the washing water of flue gas purification. Chemical Engineering Journal, 150(1, 196-203. https://doi.org/10.1016/j.cej.2008.12.025.

Egiebor, N. O., \& Oni, B. (2007). Acid rock drainage formation and treatment: a review. Asia-Pacific Journal of Chemical Engineering, 2, 47-62. https://doi.org/10.1002/apj.57.

Information brochure about TMT-15 and TMT from Evonik, www.evonik.com Accessed 26 Aug 2018.

Fogg, A. G., Ismail, R., Yusoff, A. R., Ahmad, R., \& Banica, F. (1997). Cathodic stripping voltammetric determination at a hanging mercury drop electrode of the environmental heavy metal precipitant trimercapto-s-triazine (TMT). Talanta, 44, 497-500.

Fu, F., \& Wang, Q. (2011). Removal of heavy metal ions from wastewaters: a review. Journal of Environmental Management, 92, 407-418. https://doi.org/10.1016/j. jenvman.2010.11.011.

Fu, F., Chen, R., \& Xiong, Y. (2006a). Application of a novel strategy - coordination polymerization precipitation to the treatment of $\mathrm{Cu}^{2+}$ - containing wastewaters. Separation and Purification Technology, 52, 388-393. https://doi. org/10.1016/j.seppur.2006.05.017.

Fu, F., Chen, R., \& Xiong, Y. (2006b). Removal of $\mathrm{Cu}^{2+}$ and dye from wastewater using precipitant N,N-bis(dithiocarboxy)piperazine. Environmental Chemistry Letters, 4, 41-44. https://doi.org/10.1007/s10311-005-0032$\mathrm{z}$.
Fu, F., Zeng, H., Cai, Q., Qiu, R., Yu, J., \& Xiong, Y. (2007a). Effective removal of coordinated copper from wastewater using a new dithiocarbamate-type supramolecular heavy metal precipitant. Chemosphere, 69, 1783-1789. https://doi. org/10.1016/j.chemosphere.2007.05.063.

Fu, F., Chen, R., \& Xiong, Y. (2007b). Comparative investigation of $N, N^{\prime}$-bis-(dithiocarboxy)piperazine and diethyldithiocarbamate as precipitants for $\mathrm{Ni}(\mathrm{II})$ in simulated wastewater. Journal of Hazardous Materials, 142, 437-442. https://doi.org/10.1016/j.jhazmat.2006.08.036.

Georgiadisa, M., Caia, Y., \& Solo-Gabriele, H. (2006). Extraction of arsenate and arsenite species from soils and sediments. Environmental Pollution, 141, 22-29. https://doi. org/10.1016/j.envpol.2005.08.028.

Grabas, K. (2009). Removal of heavy metal ions from an electroplating effluent and the clarified water of the "Kowary" Tailing Pond (Jelenia Gora District, Lower Silesia). Ochrona Srodowiska, 31(2), 49-54.

Henke, K. R. (1998). Chemistry of heavy metal precipitates resulting from reactions with Thio-Red®. Water Environment Research, 70(6), 1178-1185.

Henke, K. R., \& Atwood, D. A. (1998). Group 2 complexes of 2,4, 6-trimercaptotriazine (TMT). Inorganic Chemistry, 37(2), 224-227. https://doi.org/10.1021/ic970954z.

Henke, K. R., Bryan, J. C., \& Elless, M. P. (1997). Structure and powder diffraction pattern of 2,4,6-trimercapto-striazine, trisodium salt $\left(\mathrm{Na}_{3} \mathrm{~S}_{3} \mathrm{CSN}_{3} \cdot 9 \mathrm{H}_{2} \mathrm{O}\right)$. Powder Diffraction, 12, $7-12$.

Henke, K. R., Hutchinson, A. R., Krepps, M. K., Matlock, M. M., \& Atwood, D. A. (1999). Chemical precipitation of mercury: commercial claims and new approaches. Energeia, 10(10).

Henke, K. R., Robertson, D., Krepps, M., \& Atwood, D. A. (2000). Chemistry and stability of precipitates from aqueous solutions of 2,4,6-trimercaptotriazine, trisodium salt, nonahydrate (TMT) and mercury (II) chloride. Water Research, 34(11), 3005-3013. https://doi.org/10.1016 /S0043-1354(00)00038-5.

Henke, K. R., Hutchison, A. R., Krepps, M. K., Parkin, S., \& Atwood, D. A. (2001). Chemistry of 2,4,6-trimercapto-1,3,5triazine (TMT): acid dissociation constants and group 2 complexes. Inorganic Chemistry, 40(17), 4443-4447. https://doi.org/10.1021/ic0103188.

Hutchison, A. R., \& Atwood, D. A. (2003). Mercury pollution and remediation: the chemist's response to a global crisis. Journal of Chemical Crystallography, 33, 631-645. https://doi.org/10.1023/A:1024906212586.

Hutchison, A. R., Atwood, D. A., \& Santilliann-Jiminez, Q. (2008). The removal of mercury from water by open chain ligands containing multiple sulfurs. Journal of Hazardous Materials, 156(1-3), 458-465. https://doi.org/10.1016/j. jhazmat.2007.12.042.

Jha, M. C., Meyer, G. A., \& Wicker, G. R. (1981). An improved process for precipitating nickel sulfide from acidic laterite leach liquors. Journal of Metals, 33(11), 48-53. https://doi. org/10.1007/BF03339537.

Jing, X.S., Liu, F.Q., Yang ,X., Ling, P.P., Li, L.J., Long, C., Li, A.M. (2009). Adsorption performances and mechanisms of the newly synthesized N,N'-di(carboxymethyl) dithiocarbamate chelating resin toward divalent heavy metal ions from aqueous media. Journal of Hazardous Materials, 167, 589596. https://doi.org/10.1016/j.jhazmat.2009.01.020. 
Ke, Y., Chai, L., Min, X., Tang, C., Chen, J., Wang, Y., \& Liang, Y.-J. (2014). Sulfidation of heavy-metal-containing neutralization sludge using zinc leaching residue as the sulfur source for metal recovery and stabilization. Minerals Engineering, 61, 105-112. https://doi.org/10.1016/j.mineng.2014.03.022.

Kim, B. M. (1981). Treatment of metal containing wastewater with calcium sulfide. AIChE Symposium Series, 77(209), $39-48$.

Kim, J. J., Kim, Y. H., Hwang, J. A., Lim, W. T., Lee, M. H. (2014) Recovery efficiency of dissolved metal in acid mine drainage. 248th ACS National Meeting \& Exposition, San Francisco.

Koc-Jurczyk, J. (2013). Microbial removal of heavy metals from wastewater. Inzynieria Ekologiczna, 34, 166-172. https://doi. org/10.12912/23920629/330.

Krupińska, I. (2011). Prehydrlysed coagulants. Uniwersytet Zielonogórski, Zeszyty Naukowe. Inżynieria Środowiska, 141(21), 126-136.

Lewis, A. (2010). Review of metal sulphide precipitation. Hydrometallurgy, 104, 222-234. https://doi.org/10.1016/j. hydromet.2010.06.010.

Lu, F., \& Astruc, D. (2018). Nanomaterials for removal of toxic elements from water. Coordination Chemistry Reviews, 356, 147-164. https://doi.org/10.1016/j.ccr.2017.11.003.

Maila, M. D., Maree, J. P., \& Cele, L. M. (2014). Acid mine neutralization with ammonium hydroxide and desalination with barium hydroxide. Water SA, 40, 521-528. https://doi. org/10.4314/wsa.v40i3.16.

Malik, L., Bashir, A., Qureashi, A., \& Pandith, A. (2019). Detection and removal of heavy metal ions: a review. Environmental Chemistry Letters, 17, 1495-1521. https://doi.org/10.1007/s10311-019-00891-z.

Matlock, M. M., Henke, K. R., Atwood, D. A., \& Robertson, J. D. (2001a). Aqueous leaching properties and environmental implications of cadmium, lead, and zinc trimercaptotriazine (TMT) compounds. Water Research, 35(15), 3649-3655. https://doi.org/10.1016/S0043-1354(01)00091-4.

Matlock, M. M., Howerton, B. S., Henke, K. R., \& Atwood, D. A. (2001b). A pyridine-thiol ligand with multiple bonding sites for heavy metal precipitation. Journal of Hazardous Materials, 82(1), 55-63. https://doi.org/10.1016/s03043894(00)00353-8.

Matlock, M. M., Howerton, B. S., \& Atwood, D. A. (2001c). Irreversible precipitation of mercury and lead. Journal of Hazardous Materials B, 84(1), 73-82. https://doi. org/10.1016/s0304-3894(01)00190-x.

Matlock, M. M., Henke, K. R., \& Atwood, D. A. (2002a). Effectiveness of commercial reagents for heavy metal removal from water with new insights for future chelate designs. Journal of Hazardous Materials, 92(2), 129-142. https://doi. org/10.1016/S0304-3894(01)00389-2.

Matlock, M. M., Howerton, B. S., Van Aelstyn, M. A., Nordstrom, F. L., \& Atwood, D. A. (2002b). Advanced mercury removal from gold leachate solutions prior to gold and silver extraction: a field study from an active gold mine in Peru. Environmental Science \& Technology, 36(7), 1636-1639. https://doi.org/10.1021/es0112285.

Matlock, M. M., Howerton, B. S., Robertson, J. D., \& Atwood, D. A. (2002c). Gold ore column studies with a new mercury precipitant. Industrial \& Engineering Chemistry Research, 41(21), 5278-5282. https://doi.org/10.1021/ie020006s.
Matlock, M. M., Howerton, B. S., \& Atwood, D. A. (2002d). Chemical precipitation of heavy metals from acid mine drainage. Water Research, 36(19), 4757-4764. https://doi. org/10.1016/S0043-1354(02)00149-5.

Matlock, M. M., Howerton, B. S., \& Atwood, D. A. (2002e). Chemical precipitation of lead from lead battery recycling plant wastewater. Industrial \& Engineering Chemistry Research, 41(6), 1579-1582. https://doi.org/10.1021 /ie $010800 \mathrm{y}$.

Matlock, M. M., Howerton, B. S., \& Atwood, D. A. (2003a). Irreversible binding of mercury from contaminated soil. Advances in Environmental Research, 7(2), 347-352. https://doi.org/10.1016/S1093-0191(02)00010-2.

Matlock, M. M., Howerton, B. S., \& Atwood, D. A. (2003b). Covalent coating of coal refuse to inhibit leaching. Advances in Environmental Research, 7(2), 495-501. https://doi. org/10.1016/S1093-0191(02)00019-9.

Matlock, M. M., Howerton, B. S., Van Aelstyn, M. A., Henke, K. R., \& Atwood, D. A. (2003c). Soft metal preferences of 1,3benzenediamidoethanethiol. Water Research, 37(3), 579584. https://doi.org/10.1016/S0043-1354(02)00279-8.

Menezes, J., Silva, R., Arce, I., \& Schneider, I. (2010). Production of a poly-alumino-iron sulphate coagulant by chemical precipitation of a coal mining acid drainage. Minerals Engineering, 23(3), 249-251. https://doi.org/10.1016/j. mineng.2009.11.008.

Mokone, T. P., van Hille, R. P., \& Lewis, A. E. (2012). Metal sulphides from wastewater: assessing the impact of supersaturation control strategies. Water Research, 46(7), 20882100. https://doi.org/10.1016/j.watres.2012.01.027.

Monser, L., \& Adhoum, L. N. (2002). Modified activated carbon for the removal of copper, zinc, chromium and cyanide from wastewater. Separation and Purification Technology, 26, 137-146. https://doi.org/10.1016/S1383-5866(01)00155-1.

Mroczko, D., \& Zimoch, I. (2018). Coagulation of pollutions occurring in surface waters during time of dynamic water flow. Inżynieria Ekologiczna. Ecological Engineering, 19(2), 15-22. https://doi.org/10.12912/23920629/86053.

Nawrocki, J., Biłozor, S. (2010). Uzdatnianie wody, procesy chemiczne i biologiczne. PWN, Warszawa-Poznań 2010.

Nocoń, W., Kostecki, M., \& Kozłowska, J. (2006). Hydrochemical characteristic of the Kłodnica River. Ochrona środowiska, 28(3), 39-44.

Park, S., Yoo, J., Ji, S., Yang, J., \& Baek, K. (2013). Selective recovery of $\mathrm{Cu}, \mathrm{Zn}$, and $\mathrm{Ni}$ from acid mine drainage. Environmental Geochemistry and Health, 35, 735-743. https://doi.org/10.1007/s10653-013-9531-1.

Pearson, R. G. (1963). Hard and soft acids and bases. Journal of the American Chemical Society, 85(22), 3533-3539. https://doi.org/10.1021/ja00905a001.

Seo, E., Cheong, Y., Yim, G., Ji, S., \& Min, K. (2014). Effect of oxidation on selective precipitation of dissolved $\mathrm{Fe}, \mathrm{Al}$ and $\mathrm{Mn}$ in acid mine drainage during neutralization. Journal of the Korean Society of Mineral and Energy Resources Engineers, 51, 232-239.

Sheoran, A. S., \& Sheoran, V. (2006). Heavy metal removal mechanism of acid mine drainage in wetlands: a critical review. Minerals Engineering, 19(2), 105-116. https://doi. org/10.1016/j.mineng.2005.08.006.

Skousen, J. (2014). Overview of acid mine drainage treatment with chemicals. In J. A. Jacobs, J. H. Lehr, \& S. M. Testa 
(Eds.), Acid mine drainage, rock drainage, and acid sulfate soils (pp. 327-337). Hoboken: Wiley. https://doi. org/10.1002/9781118749197.ch29.

Skousen, J., Sexstone, A., \& Ziemkiewicz, P. F. (2000). Acid mine drainage control and treatment. In R. Barnhisel, R. Darmody, \& W. Daniels (Eds.), Agronomy (pp. 131-168). Wiley. https://doi.org/10.2134/agronmonogr41.c6.

Stén, P., \& Forsling, W. (2000). Precipitation of lead sulfide for surface chemical studies. Colloids and Surfaces A: Physicochemical and Engineering Aspects, 172(1-3), 1731. https://doi.org/10.1016/S0927-7757(00)00588-4.

Tarabocchia, J., Karg, A. (1990). Printed circuit board waste treatment removes metals, reduces costs. Plating and Surface Finishing. February, $24 \pm 26$.

Tassel, F., Rubio, J., Misra, M., \& Jena, B. C. (1997). Removal of mercury from gold cyanide solution by dissolved air flotation. Minerals Engineering, 10(8), 803-811. https://doi. org/10.1016/S0892-6875(97)00058-7.

Thomas, M., Białecka, B., \& Zdebik, D. (2014). Sources of copper ions and selected methods of their removal from wastewater from the printed circuits board production. Inzynieria Ekologiczna, 37, 31-49. https://doi.org/10.12912/2081139 X.15.

US Environmental Protection Agency (US EPA) (2000). wastewater technology fact sheet chemical precipitation, 832-F-00-018, Washington, DC.

Wang, L. K., Vaccari, D. A., Li, Y., \& Shammas, N. K. (2004). Chemical precipitation. In L. K. Wang, Y. T. Hung, \& N. K. Shammas (Eds.), Physicochemical treatment processes (pp. 141-198). New Jersey: Humana Press. https://doi. org/10.1385/1-59259-820-x:141.

Wang, F., Ji, Y., Wang, J. (2012). Synthesis of heavy metal chelating agent with four chelating groups of $\mathrm{N}^{1}, \mathrm{~N}^{2}, \mathrm{~N}^{4}, \mathrm{~N}^{5}$ tetrakis(2-mercaptoethyl)benzene-1,2,4,5-tetracarboxamide (TMBTCA) and its application for Cu-containing wastewater. Journal of Hazardous Materials, 241-242, 427-432. https://doi.org/10.1016/j.jhazmat.2012.09.067.
Wei, D., \& Osseo-Asare, K. (1996). Particulate pyrite formation by the $\mathrm{Fe}^{3+} / \mathrm{HS}$-reaction in aqueous solutions: effects of solution composition. Colloids and Surfaces A: Physicochemical and Engineering Aspects, 118(1-2), 5161. https://doi.org/10.1016/0927-7757(96)03568-6.

WST Water Specialists Technologies LLC (Product informationThio Red), www.waterspecialists.biz Accessed Sept 10 2018.

Yan, X. P., Li, Y., \& Jiang, Y. (2003). Selective measurement of ultratrace methylmercury in fish by flow injection on-line microcolumn displacement sorption preconcentration and separation coupled with electrothermal atomic absorption spectrometry. Analytical Chemistry, 75, 2251-2255. https://doi.org/10.1021/ac026415f.

Zaman, K. M., Blue, L. Y., Huggins, F. E., \& Atwood, D. A. (2007a). Cd, hg, and $\mathrm{Pb}$ compounds of benzene-1,3diamidoethanethiol $\left(\mathrm{BDETH}_{2}\right)$. Inorganic Chemistry, 46(6), 1975-1980. https://doi.org/10.1021/ic0607639.

Zaman, K. M., Chusuei, C., Blue, L. Y., \& Atwood, D. A. (2007b). Prevention of sulfide mineral leaching through covalent coating. Main Group Chemistry, 6, 169-184. https://doi.org/10.1080/10241220802075723.

Zhena, H., Xu, Q., Hu, Y., \& Cheng, J. (2012). Characteristics of heavy metals capturing agent dithiocarbamate (DTC) for treatment of ethylene diamine tetraacetic acid-Cu (EDTA$\mathrm{Cu})$ contaminated wastewater. Chemical Engineering Journal, 209, 547-557. https://doi.org/10.1016/j. cej.2012.08.045.

Zhuang, J. (2009). Acidic rock drainage treatment: a review. Recent Patents on Chemical Engineering, 2(3), 238-252. https://doi.org/10.2174/2211334710902030238.

Publisher's Note Springer Nature remains neutral with regard to jurisdictional claims in published maps and institutional affiliations. 